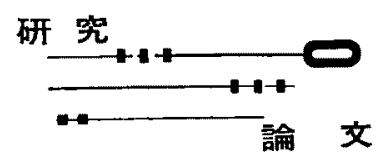

\title{
660. 燃料集合体内の冷却材流れによる燃料捧の振動
}

岡崎 元 昭*,山崎弥三郎*

\author{
(1977年 6 月17日 受理)
}

\begin{abstract}
Fuel Rod Vibration Induced by Coolant Flow in Rod Assembly
\end{abstract}
By Motoaki OKAZAKI and Yasaburo YAMAZAKI

\begin{abstract}
Fuel rod vibration induced by coolant flow is subjected to not only the rod characteristics such as specific gravity, flexural rigidity and supporting condition at the spacer grid but also the flow conditions influenced by the geometry of flow path.

This paper presents the experimental results of fuel rod vibration induced by water and airwater two phase flow in JPDR-II type and Advanced Thermal Reactor (FUGEN) type fuel assembly, using model fuel rod which has the same characteristics to the actual fuel rod assemblies.

It was revealed that the correlations presented by Burgreen, Paidoussis and Reavis were insufficient to estimate the actual fuel rod vibrations because of differences in the fuel rod and flow characteristics on fuel rod vibration phenomena.
\end{abstract}

KEYWORDS: fuel rod, vibration, coolant flow, water, air-water two phase flow, fuel rod assemblies

\section{I. 序 論}

然料棒を規則的に配列した原子炉然料集合体では， 核・熱設計上の必要から然料棒の配列ピッチ間隔が定 められ，それを維持するためスペーサーが設けられ る。スペーサーは一般に狭い棒間隙に設けなければな らないので,スベーサーが流れの断面積の中に占める 割合は大きい。その結果，冾却材流れにより然料集合 体内で発生する氏力損失のちち，スペーサーで生ず る分の占める割合はかなり大きい。また，中性子吸収 るここで生ずるので，スペーサーの設闐間隔をなるべ く大きくして設置個数を少なくすることが要求され る。

しかし，燃料被覆管は製造過程である程度の曲りが 生ずる上に，照射によっても曲りが生ずる。さらに， 冾却材流れ注上る然料棒の曲げ振動子発生する。した

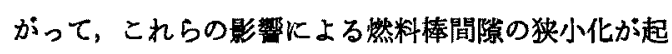
っても，然料棒間に定められた必要最小間鵪が維持さ れるよろにスペーサーの設置間隔が定められなければ
ならない。また，然料棒の振動はスペーサーによる支 持部で被覆管との間浪細かい摩摖を生しさせせフンッ ティング腐食 (fretting corrosion) と呼ばれる被覆管の 腐食を引き起すことが知られている。フレッティング 腐食はスペーサーによる保持状態之然料棒の振動数に 関係するといわれており，原子炬の安全確保上大きな 問題の一つである**。

以上の諸点から，冷却材流れに上る然料棒の振動数 および振幅に関する知見を得ることは，スベーサーの 設置間隔を定める上にも，原子炉の安全確保上にも重 要である。

* 日本原子力研究所 (Japan At. Energy Res. Inst.)

**著者らは㜣料棒の振動問題について研究を進める らちに，往来のスベーサーは振野によるフレッテ イング腐食の発生に対して, 上り耐性のある構造 であるべきことの必要を痛感した。そこで, 振動

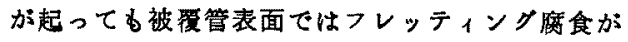
起らない構造を有すると同時に，椹造が簡単で流 動抵抗の少ないホールディング・スペーサーと呼 ぶの考案して報告した(゙)。 
Table 1 Range of experiments of various investigators

\begin{tabular}{|c|c|c|c|c|c|c|c|}
\hline \multirow{2}{*}{ Item } & \multirow{2}{*}{ Paidoussis ${ }^{(5)}$} & \multirow{2}{*}{ Sogréah ${ }^{(3)}$} & \multirow{2}{*}{ Quinn ${ }^{(2)}$} & \multirow{2}{*}{ Burgreen $^{(1)}$} & \multirow{2}{*}{ Pavlica $^{(4)}$} & \multicolumn{2}{|c|}{ This paper } \\
\hline & & & & & & JPDR-II & ATR \\
\hline $\begin{array}{l}\text { Diameter of pipe } \\
\text { for fluid flow }(\mathrm{mm})\end{array}$ & 100 & 300 & $16,31.7,41.4$ & 160 & $\sim 60$ & $119^{\square}$ & 117.8 \\
\hline Number of rods & 1 & 1 & $\begin{array}{l}\text { 36 (water flow) } \\
1 \text { (two-phase } \\
\text { flow) }\end{array}$ & $1,13,37$ & 16 & 49 & 28 \\
\hline Diameter of rod & $15.7 \sim 19.3$ & 12.0 & 9. 86 & $12.7,15.9$ & 11.1 & 12.23 & 16.81 \\
\hline $\begin{array}{l}\text { Specific gravity } \\
\text { of rod }\end{array}$ & $0.55 \sim 3.23$ & $\begin{array}{c}\text { 3. } 42 \text { (stainless } \\
\text { steel) }\end{array}$ & $\begin{array}{l}6 \% \text { lighter } \\
\text { than actual } \\
\text { fuel rod }\end{array}$ & $\begin{array}{l}0.9 \sim 2.7 \\
\text { (Al pipe) }\end{array}$ & 9.15 & 9.4 & 9. 34 \\
\hline $\begin{array}{r}\text { Supported length } \\
(\mathrm{mm})\end{array}$ & 518. $2 \sim 924.6$ & 1,200 & $1,874.5$ & $\sim 1,200$ & $\sim 1,800$ & 540 & 400,800 \\
\hline $\begin{array}{l}\text { Hydraulic diameter } \\
(\mathrm{mm})\end{array}$ & $47.5 \sim 86.4$ & 288 & $\begin{array}{l}6.1,21.8, \\
31.5\end{array}$ & $\begin{array}{c}142(1 \text { rod }) \\
60(13 \text { rods }) \\
21.4(37 \text { rods })\end{array}$ & $\sim 13.6$ & 14.06 & 9.83 \\
\hline $\begin{array}{l}\text { Fluid velocity } \\
\qquad(\mathrm{m} / \mathrm{sec})\end{array}$ & 1. $2 \sim 12$ & - & $0.84 \sim 11.4$ & $1.8 \sim 6.5$ & $3 \sim 12$ & $\stackrel{0.667}{\sim 2.34}$ & $\stackrel{1.83}{\sim 3.67}$ \\
\hline Two-phase flow & None & None & $\begin{array}{c}\text { Pressure: } 70 \text { ata } \\
\text { Quality: } 0.02, \\
0.05,0.15\end{array}$ & None & None & $\begin{array}{l}\text { Void ratio: } \\
\text { at atmospher }\end{array}$ & $\begin{array}{l}0 \sim 0.60 \\
\text { ric pressure }\end{array}$ \\
\hline $\begin{array}{l}\text { Condition of fluid } \\
\text { flow }\end{array}$ & $\begin{array}{l}\text { Horizontal } \\
\text { test section } \\
\text { circulated } \\
\text { by pump } \\
\text { Room temp. }\end{array}$ & $\begin{array}{l}\text { Horizontal } \\
\text { test section } \\
\text { flowing by } \\
\text { gravity from } \\
\text { head tank } \\
\text { Room temp. }\end{array}$ & $\begin{array}{l}\text { Vertical test } \\
\text { section } \\
\text { circulated by } \\
\text { pump } \\
\text { Temp. : } 25, \\
93,260^{\circ} \mathrm{C}\end{array}$ & $\begin{array}{l}\text { Vertical test } \\
\text { section } \\
\text { circulated by } \\
\text { pump } \\
\text { Room temp. } \\
\quad\left(14 \sim 36^{\circ} \mathrm{C}\right)\end{array}$ & $\begin{array}{l}\text { Vertical test } \\
\text { section } \\
\text { circulated by } \\
\text { pump } \\
\text { Temp. : } 21 \text {, } \\
65^{\circ} \mathrm{C}\end{array}$ & $\begin{array}{l}\text { Vertical to } \\
\text { circulated } \\
\text { Room tem }\end{array}$ & $\begin{array}{l}\text { est section } \\
\text { by pump } \\
\text { np. }\left(25^{\circ} \mathrm{C}\right)\end{array}$ \\
\hline
\end{tabular}

\section{I. 従来の研究とその問題点}

流れに平行に膡かれた棒の振動に関するこれまでの 研究Kは, Burgreen ${ }^{(1)}$, Quinn $^{(2)}$, Sogréah ${ }^{(3)}$, Pavlica $^{(4)}$, Paidoussis(5), Reavis(6) その他のものがあり，この中で, 流れによる㭏の振動振幅の実験式を導いているものに は Burgreen, Paidoussis ならびに Reavis のむのがあ る。Table 1 にこれらの実験のパラメータを示す。 Burgreen および Reavis の各実験式は水単相流のみに 対するものであり，Paidoussis のるののみが水単相流 および気液二相流に共用でさるすのである。

これらの実験式を導くに当って採用された実験デー タは，振動棒としては実際の然料棒より軽い材質の管 または丸棒によるものばかりである。また，流路とし ては，水単相流に対しては円管内に単一の振動棒が㗐 かれている場合と，管束流路内に振動棒か涺かれてい る場合との両方が採用されているか，気液二相流に対 して作成された Paidoussis の実験式は，Quinn の行 なった直径 $40 \mathrm{~mm}$ 程度の円管内に単一の振動棒が直か れている場合の実験データのみしか採用していない。 しかし，実際の沸滕水炉の然料集合体内では，このよ らに小さな直径の円管内での二相流動状態とは大きく
異なり，非常に大きな乱れを有する流れである。それ は，実規模の然料集合体内における二相流は，ボイド 率がかなり大きくなってる流動様式が気泡流であると いら事実(8)からす裹付けられる。さらに，実験式を作 成するに当って採用されたデータは，振動棒の剛珄， 支持間隔ならびに単位長さ当りの重量が串炉の場合と 大きく異なる。

したがって，これらの実験式が実灯における燃料棒 の振動振幅をどれはど正確に予測するるのであるかに ついては不明である。そこで，著者らは実炬における 然料集合体と同一形状, 同一重量, 同一㴊性を有する然 料集合体ならびに模擬棒を用いて水単相流と常王の空 気一水二相流とによる実験を行い，振動数と振幅に関す る特性を調べた。対象とした然料集合体はJPDR-IIな らびに新型転换师(ATR) 2 次設計によるすのである。

その結果，実妒における然料棒の振動振幅は，従来 の実験式によって計算される值よりすずっと大きいこ と，特に二相流の場合は 1 㟁以上る大さく，かつその 特性を実験式の示す傾向とは全く異なることが明らか となった。 


\section{III. 実験装置}

\section{1. 実匰ルーフ}

テスト・ルーブとしては常圧然料体流動試駼装圈(9)を 用いた。これは実規模の然料集合体の流動試験装固で 最大 $10 \mathrm{~kg} / \mathrm{cm}^{2} \cdot \mathrm{g}$ の空気一水二相流に上る流動試験が 行える。テスト部長さは $5 \mathrm{~m}$ あっテテスト部出口後少 しの助走区間を経て気水分離タンクがある。ここで気 水分離された水はポンプによって再びテスト部入口下 送られる。テスト部入口には，小さな究が数多くあけ られたバーナー型ミキサーが設けられて批りっここよ り正空が吹き込まれて空気一承二相流が作られる。テ スト部内のボイド率はテスト部出入口に設けられた 2 個の急速廘断弁によって測定される。また，テスト部 へ送られる水流量は面皘式流量計，空気流量は絞り流 量計によって測定した。

\section{2. 訪験用然料集合体}

テスト部として用いた然料集合体は JPDR-II 用の るの(9)と ATR 2 次設計用のすの地とである。これらは 両者ともジルカロイー2 製の被覆管が使われている。

JPDR-I然料集合体では，外径 $12.23 \mathrm{~mm}$ ，内径 10.83 $\mathrm{mm}$ の被覆管が $7 \times 7$ の格子状にピッチ $16.6 \mathrm{~mm}$ で配 列されている。被覆管内に性外径 $10.71 \mathrm{~mm}$ ，長さ 20 $\mathrm{mm} の \mathrm{UO}_{2}$ ペレットが封入されており，然料棒単位 長さ当りの質量は $0.1126 \mathrm{~kg} \cdot \mathrm{sec}^{2} / \mathrm{m}^{2}$ である。また，被 覆管の曲げ剛性 $E I$ はジルカロイー2のヤング率を $E$ $=10^{4} \mathrm{~kg} / \mathrm{mm}^{2}$ として $E I=4.23 \mathrm{~kg} \cdot \mathrm{m}^{2}$ である。スペー サーにはたわみワイヤ・スペーサーか使われて批り， $540 \mathrm{~mm}$ 間隔で設置されている。

次節で述べる振動測定用模擬棒は $7 \times 7$ 配列の中央 に取り付けた。

ATR 2 次設計燃料集合体では, 外径 $16.81 \mathrm{~mm}$, 内径 $15.09 \mathrm{~mm}$ の被覆管が内径 $117.8 \mathrm{~mm}$ の圧力管内に 3 層 の同心円上に全部で28本配列されている。被覆管内に は外径 $14.80 \mathrm{~mm}$, 長さ $20 \mathrm{~mm}$ の $\mathrm{UO}_{2}$ ペレットが封入 されており，然料棒単位長さ当りの質量は $0.2115 \mathrm{~kg}$. $\mathrm{sec}^{2} / \mathrm{m}^{2}$ である。また，被覆管の曲げ剬性 $E I$ は 10.5 $\mathrm{kg} \cdot \mathrm{m}^{2}$ である。スペーサーKはリング型スペーサー舟 が使われており，412 mmの間隔で設置されている。 振動測定用模擬棒は，3 層の同心円上に配着されて

\begin{tabular}{|c|c|c|}
\hline & 名 称 & $\begin{array}{l}\text { スベーサー設置 } \\
\text { 間隔( } \mathrm{mm} \text { ) }\end{array}$ \\
\hline 第 1 層(中心部) & $\mathbf{a}$ & 412 \\
\hline 第 2 層 ＂ & b & 824 \\
\hline 第 3 層(管壁部) & c & 412 \\
\hline
\end{tabular}

いる燃料棒の各層から1本ずつをとり，前表のように 定めた。

\section{3. 振動測定用模㩧浾}

ATR の場合は，実物のジルカロイー2 製被覆管を 用いた。JPDR の場合は冷間引抜きによる脱酸銅製被 覆管を用いたが，肉厚を $0.5 \mathrm{~mm}$ としたので $E I=$ 4. 14 4. $27 \mathrm{~kg} \cdot \mathrm{m}^{2}$ となり, 前節で述べたジルカロイー 2 製の被覆管における $4.23 \mathrm{~kg} \cdot \mathrm{m}^{2}$ とほぼ同じとなって いる。

被覆管内には UO $\mathrm{UO}_{2}$ ペレットと同重量,同寸法の鉛ぺ レットを封入して単位長さ当りの重量を同しにしてあ る。ただし，UO $\mathrm{UO}_{z}$ ペレットの比重が 10.41 に対し，鉛 (フンチモンを微量含んた硬化鉛を用いた)の比重は 11.3なので，鉛ベレットの中心には小さな穴があけら れている。この穴は後述するよ5に歪測定用の半導体 ゲージのリード線を貫通する穴として使っている。

振動の測定は，スペーサーによる支持間隔の中央位 直の被覆管内面に貼付された半導体ゲージによって行 なった。半導体ゲージは管内面の円周上に $90^{\circ}$ 間隔で 4 枚貼付し，対向する 2 枚のゲージが 1 対となって 2 ダージ法による湘定を行らように内部で結線されてい、 る。したがって，直角方向の歪がそれぞれ分離して動 歪計により湘定される。

半導体ゲージを被覆管内面に貼付する手順は次のよ らである。まず，貼付すべき位固付近で被覆管を切断 し，その部分を機械加エして止まりばめ程度の棪合構 造にする。次に，管端面から治具を差し込んでゲージ を貼付すべき位直に $90^{\circ}$ 間隔で管軸に平行に 4 枚の半 導体ゲージを貼付する。半導体ゲージを貼付した部分 の鉛ブロックはダージが当らないよらに溝を切り，そ こからゲージから出ているリード線の通り道を，鉛ブ ロックの中央汇設けた穴まで作る。ゲーシ上に位置す る鉛ペレットは $1 \mathrm{~mm} \phi$ のまわり止め用ピンで被覆管 上に固定される。次に，嵌合部を接続するために，定 盤の上KVブロックを1直線上に置き，その上に被復 管を族合部をつき合わせて乗せておく。そして，椾合 部に強力瞬間接着剤を染布してVプロック上で被覆管 を素早くすべらせて接統する。接着後の固定強度を碓 実にするため円周上の 2 万向から $1 \mathrm{~mm} \phi$ のピン止め をした。リード線は鉛ペレットの中央穴を通って然料 棒上部端栓より取り出され，さらに圧力管のノズル から油れ止め機構を通って圧力管の外へ取り出され る。

\section{4. 振動斯測鱾绿装贯}

これらの装置のブロック因をFig.1亿示す。以下に 


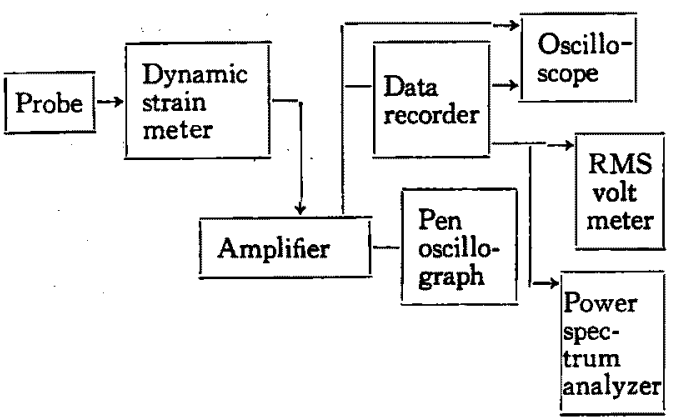

Fig. 1 Block diagram of instrumentation

主要機器の主要仕様を記す。動昰計は周波数応答特性 מi $\mathrm{DC} \sim 2,000 \mathrm{~Hz}$, 最大感度の $100 \times 10^{-6} / 1 \mathrm{~V} / 10 \mathrm{k} \Omega$ の とさ入力換算で $4 \times 10^{-6}$ 歪みの雑音を含さるのである。 半学体ゲージは長さ $8 \mathrm{~mm}$, 幅 $0.6 \mathrm{~mm}$, 厚さ0.03 $\mathrm{mm}$

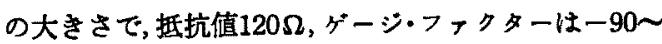
- 120 , 許容西量 $3,000 \times 10^{-6}$ を有する。パワー・スヘ クトラム・アナライザはハンンド・パスフィルタによる 実時間分析方式のすのを用いた。

さらに，振動計测用模提棒の健全性を調べ，㓮珄率 を検定するための検定装椇る別に製作した。これは模 擬棒を全く曲げ応力が加えられていない雨端固定状的 で垂直に立てた後，中央で適当な集中荷重を加えるこ とにより，そこでの棒の変位と半臫体ゲージで検出さ れた歪量との関係を求める装置である。棒中央での微 小变位は $0.001 \mathrm{~mm}$ の最小目盛を有する測微鏡を用い た。また，検定装置に装荷された状㑷における樯の固 有振動数を計測することにより，前述の検定結果と合 わせて棒の用性率ならびに模揟棈に貼付された状態に おける半導体ゲージのゲージ・ファクターを求める。

次に，模颃棒が燃料集合体の中に組み込まれた状熊 でのスベーサー支持による棒の固有振動数を求める。 それは然料集合体を吊り下げた状態でスペーサー部 を軽く吒いて掁動させることにより達せられる。

\section{IV. 実験結果と考察}

\section{1. 模霹棒の検定結果}

JPDR-II 用模㘈棒の場合，最大感度を有する $2 つ の$ 方向の曲げに対し，それぞれの曲げ㓮性 $E I$ は $E I_{1}=$

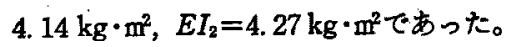

然料集合体の中に装荷された状態でのたわみワイヤ 型スベーサー支持による模擬棒の国有振動数は44, 54, $75 \mathrm{~Hz}$ の 3 種類の周波数成分が測定された。これはた わみワイヤ型スペーサーの支持状熊を考えると，ワイ ヤが模擬棒を押しつけている方向とそうでない方向と
で大きく異なる 2 つ振動数成分が存在すること，ま た，その中間で振動しゃすい方向のあるためと考えら れる。

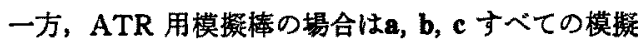
棒て扰よそ $E I=10.5 \mathrm{~kg} \cdot \mathrm{m}^{2}$ であった。そして，然料 集合体の中に装荷された状熊でのリング型スペーサー 支持による模擬排の固有振動数は a と cでは 102.5 $\mathrm{Hz}$ ，bでは 19.6 Hz であった。そのほかに a,b, cに共 通に現れた固有振動数成分 $32.5 \mathrm{~Hz}$ が存在したが，こ れはべースを支点とした集合体全体の固有振動数と考 党られる。

\section{2. 流体中での振勤実歌結果}

実験は, 水単相流の場合流速約 $1 \sim 3.7 \mathrm{~m} / \mathrm{sec}$ の範囲 で行い, 空気一水二相流の場合最大約 $60 \%$ のボイド率 まで行なった。温度,圧力はそれぞれ常温,常圧であ る。なおこれまで行われた他の研究者の実験条件と の比較表はTable 1 に示してある。

\section{(1) 振動数}

JPDR-II用模擬棒の場合，水単相流ならびに空気一水 二相流の両方の流動条件を通じて，たわみワィヤ型ス

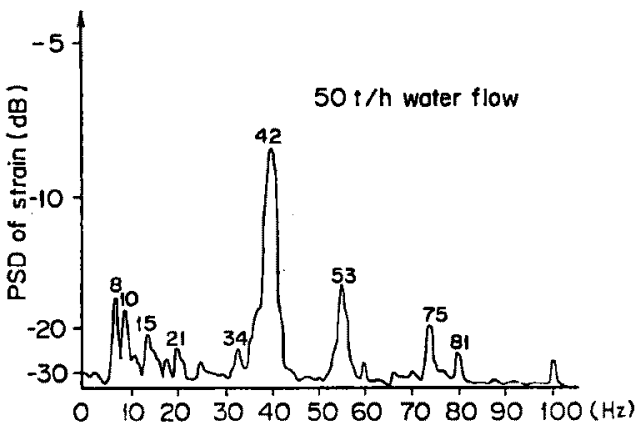

(a) Water flow

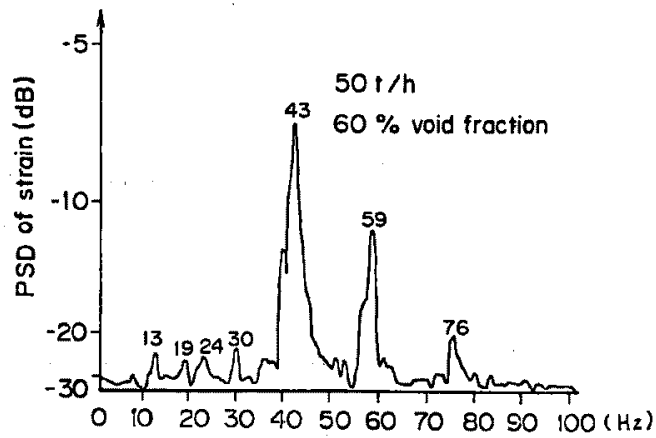

(b) Air-water two-phase flow

Fig. 2. Power spectral density (PSD) of dynamic strain by rod vibration in JPDR-II assembly 
ペーサー支持間の棒の固有振動数である $44,54,75 \mathrm{~Hz}$ の成分と，然料集合体全体としての固有振動成分とみ られる $12 \mathrm{~Hz}$ の成分とがある。これらの振動数成分の らち最も大きいパー・スペクトラム密度を示すのは $44 \mathrm{~Hz}$ 成分であり, $54,75 \mathrm{~Hz}$ の成分はこれに比較して半 分以下である。12 Hz の成分はこれらに比べてすずっ と小さい。代表例として水流量 $50 \mathrm{t} / \mathrm{hr}$ (水流速 $1.67 \mathrm{~m} /$ sec)の単相流の場合の周波数分析結果をFig. 2 (a) 水流量 $50 \mathrm{t} / \mathrm{hr}$ ，ボイド率 $60 \%$ の場合のそれを Fig. 2 (b)に示す。

ATR 用模擬棒の場合，シング型スペーサー支持間 隔が $412 \mathrm{~mm}$ である a,c の模擬棒の場合と, スペーサー 支持間隔が $824 \mathrm{~mm}$ であ るbの場合とで振動数の 現れ方が異なる。Fig. 3 K60 t/hr 水単相流 (水流 速 $2 \mathrm{~m} / \mathrm{sec}$ )の場合のa, b. c 各模提棒化括汀る 周波 数分析結果を示す。 $a$ と cでは水単相流の場合 $100 \mathrm{~Hz}$ と $28 \sim 35 \mathrm{~Hz}$ の 2 つの卓越成分が存在する が,これらは空気中での スペーサー支持による固 有振動数である102. $5 \mathrm{~Hz}$ とベースを支点とした然 料集合体全体の固有振動 数である $32.5 \mathrm{~Hz}$ にそれ ぞれ相当するすのと考え られる。流水中であるた めそれぞれの成分が僅か ずつ変化しているすの
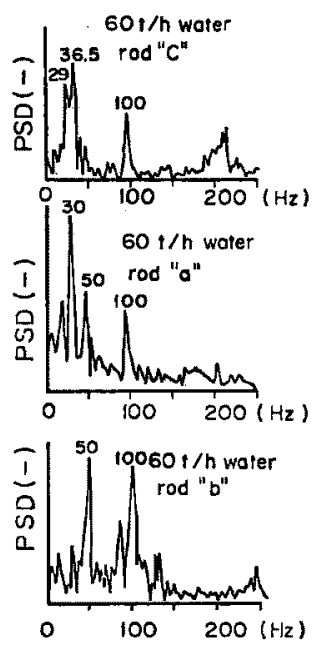

Power spectral densities (PSD) of dynamic strain by rod vibration induced by water flow in ATR assembly

Fig. 3 見られる。bでは水単相流の昜合 $100,85,50 \mathrm{~Hz}$ の成 分が存在する。 $85 \mathrm{~Hz}$ 成分は空気中でのスペーサー支 持による固有振動数である約 $20 \mathrm{~Hz}$ の第 3 次モードの 振動数と考えられるが， $50,100 \mathrm{~Hz}$ の成分電源ノイ ズを拾ったるのではないかと考えられる。

以上のことから、スペーサー支持間隔が小さな場合 は流水中の模擬棒の振動は 1 次モードであるが，スペ 一サー支持間隔が大きくなると 1 次モードの定常的振 動は現れにくくなり，ランダムな振動になる傾向にあ ることが認められる。このことは，流水中の模擬棒の 振動は流水中の乱れによる広い周波数成分を含さ变動 王力が棒に対する励振力となっていることを暗示させ る。これは二相流中での模擬棒の掁動が a, b, cでボイ
ド率の増加ととむによ゙のように変化するかを調べるこ とによってさらに明らかになる。

Fig. 4 (a) 飞水流量 $30 \mathrm{t} / \mathrm{hr}$ ，ボイド率 $10.5 \%$ の場 合, Fig. 4(b) k水流量 $30 \mathrm{t} / \mathrm{hr}$, ボイド率 $52 \%$ の場 合の各模擬棒に批ける周波数分析結果を示す。
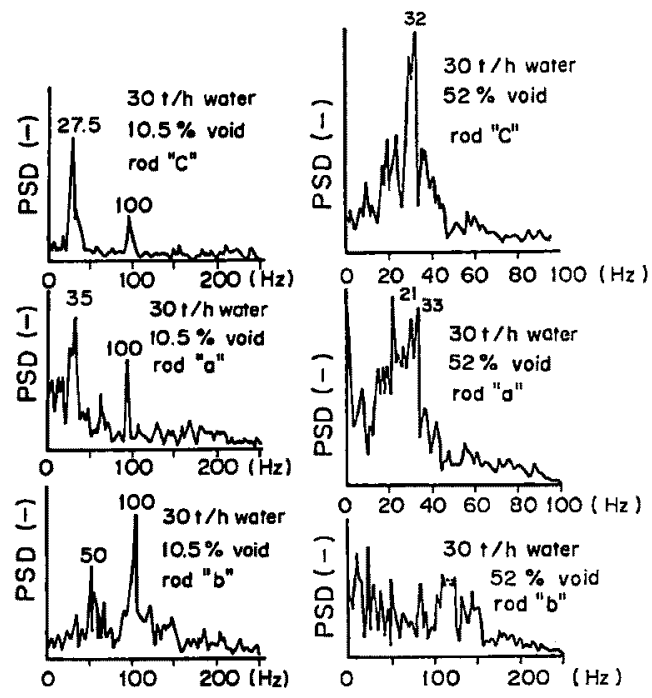

(a) $10.5 \%$ void

(b) $52 \%$ void

Fig. 4 Power spectral density (PSD) of dynamic strain by rod vibration induced airwater two-phase flow in ATR assembly

Fig.4(a), (b)から，bでは二相流中のボイト率の増 加ととあに振動による歪みのパワー・スペクトル密度 はフラットな分布を示すよらになることがわかる。ま た： 、 cでは 1 次モードの振動数成分にはビークが 現れなくなり，集合体全体の固有振動数付近にピーク

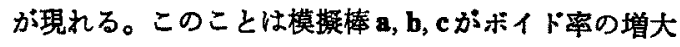
とともに乱流中の圧力変動による模擬棒への励振力か 強くなるため，模提棒の固有振動からランダム振動に 移行していることを示していると考えられる。ここで いらランダム振動の意味は，振動数がランダムである といら意味はもらろん，模擬棒の振動による変形状態 が sine 状ではなく，複雑な变形曲線を描いているとい ら意味をす含えでいる。

\section{(2) 振 幅}

前節での流水中における模擬棒の周波数分析結果か ら，流水中の乱れによる变動圧力が大きくなると，振 動数がランダムになるばかりでなく，模擬棒の変形状 態む複雑な形になることが予想された。しかし，振幅 の計算に当って，ここでは計湘された青量から予想さ れる最む大きな変位を考えて計算することにする。 
一般に，棒の曲げによる昰量 $\varepsilon$ と変位 $\delta$ の関係は， 材料力学の公式か.

$$
\frac{\delta}{\varepsilon}=K_{0} \frac{l^{2}}{t}
$$

ここで，振動する棒の变形状態での $K_{0}$ の值は文献(1) $\Sigma b$

$$
\begin{aligned}
& K_{0}=\frac{1-\frac{\cosh \beta l / 2}{\cos \beta l / 2}}{2\left(\frac{\beta l}{2}\right)^{2}\left(1+\frac{\cosh \beta l / 2}{\cos \beta l / 2}\right)} \\
& こ こ て, \quad \beta l=\sqrt{\rho A \omega_{n}{ }^{2} / E I} \\
& l \text { ：棒の固定間距離 } \\
& \rho: \text { 棒の密度 } \\
& A \text { ：棒の断面皘 } \\
& \omega_{n} \text { : 固有の角周波数 } \\
& E I \text { : 曲げ㓮性 } \\
& t \text { : 被裂管の内半径 }
\end{aligned}
$$

この時 $\delta$ は中立軸よりの変位になる。 $K_{0}$ はVー1節で 求められた固有振動数と曲げ剛性から，JPDR-II の被 覆管に対して0.139，ATR のそれに対してaとcで は0.161，bでは0.19と計算された。

Fig. 5 (a)に JPDR-II 然料集合体における水単相流 による振幅の RMS值を水流量に対してプロットした bのを示す。Fig. 5 (b) に ATR 然料集合体の場合に ついて同様にブロットしたすのを示す。

次に，常温・常匠の空気-水二相流での実験結果から， Fig. 6 (a) にJPDR-II の場合について水流量をバラメ 一タとしてボイド率に詨する振幅值を示す。Fig. 6 (b)にATR 燃料集合体の場合について同様の関係を プロットしたものを示す。Fig.5〜6に示すように， 両模擬棒とも二相流になると模擬棒の振幅は急激に増 大する。そして，二相流による振幅は水流量にほとん ど無関係でボイド率のみに依存しており，ボイド率が 0 から30〜40\%の間はボイド率の増大によって振幅が 大きく增加するが，それ以上のボイド率になると振幅 の増加の割合は減少してゆく。

ここで，ATR 燃料集合体での結果から，棒の支持 間隔の大きさが模擬棒の振幅値に与光る影響を見てみ る。単相流の場合, 流量の低い所ではbの振幅は、あ るいはc の約 4 倍になっており，（1)式で示されるよ

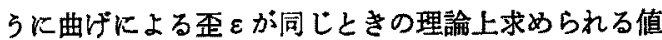
にほぼ近い。しかし，流量の増大につれてこの倍率は 低くなる傾向が見られる。これは模擬棒の長さが長く なればなるはと，また流速が大きくなればなるはど流 れの乱れによる棒への励振力が棒全長への合成值とし

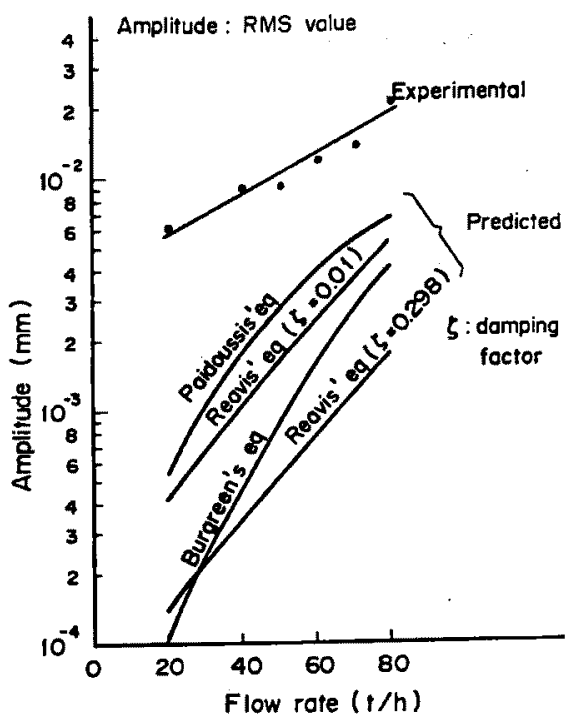

(a) JPDR-II assembly

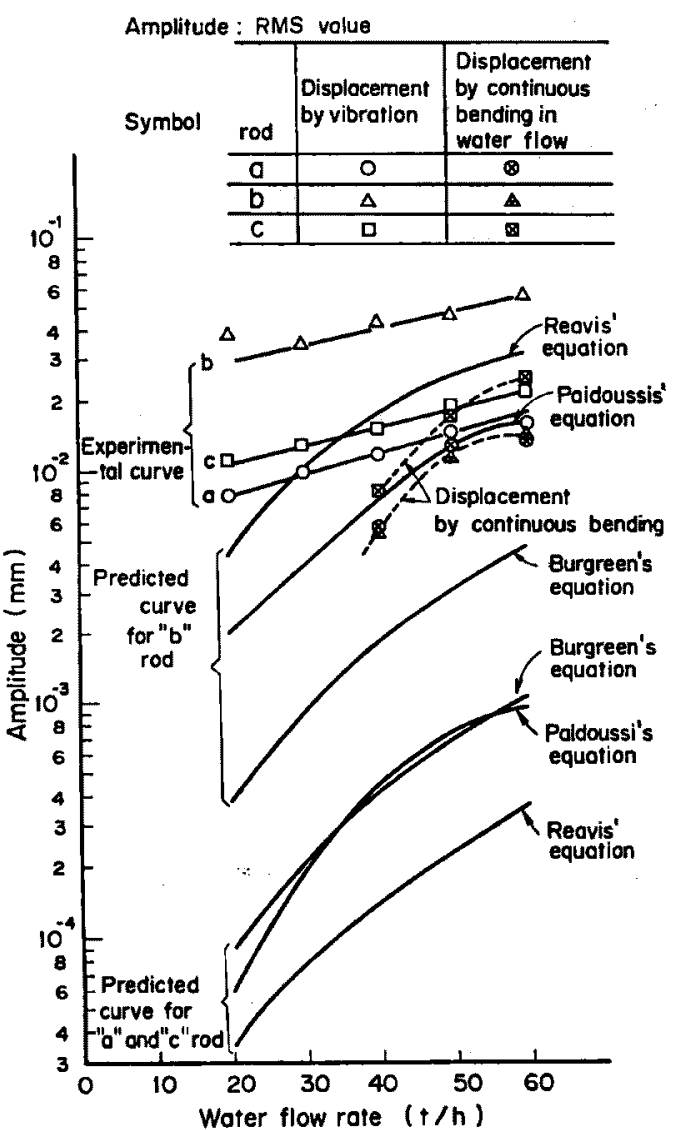

(b) ATR assembly

Fig. 5 Amplitude of rod vibration in water flow 


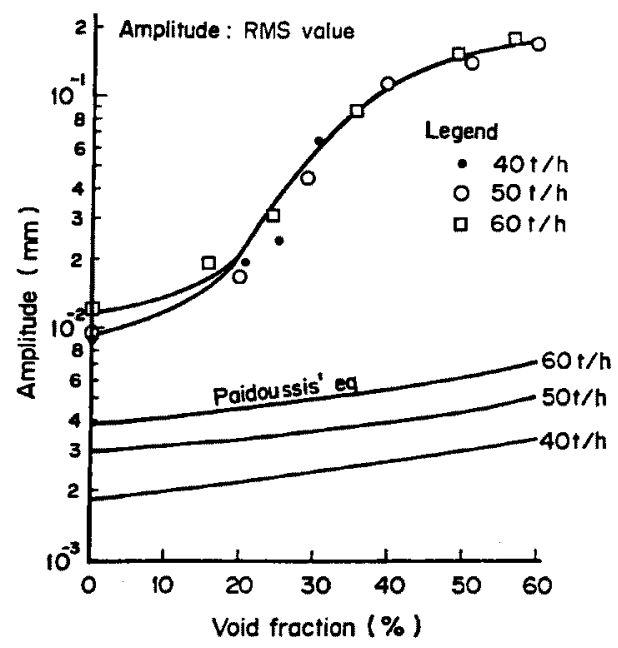

(a) JPDR-II assembly

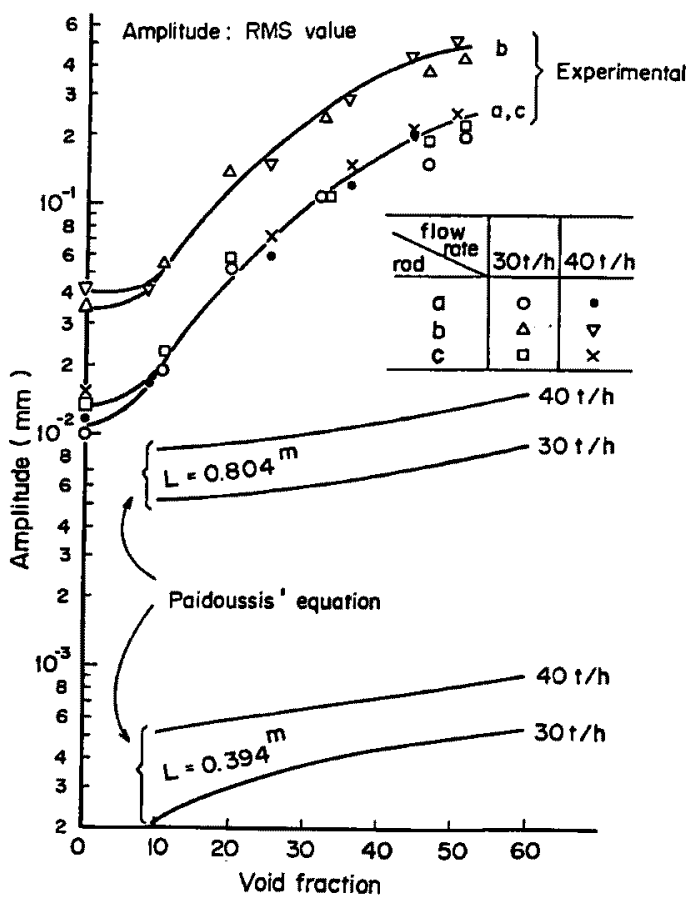

(b) ATR assembly

Fig. 6 Amplitude of rod vibration in two-phase flow

て、その大きさが小さくなるためであると考えられ る。この傾向は二相流の場合，流れの乱れが大きいた め湿著である。ここでいら乱れとは流路内で流れが無 秩序に摜乱している現象を意味し，これが棒の横方向 への空間的, 時間的にランダムな荷重となっている。
な拈，単相流の場合，燃料集合体中央に位置する a と最外周に位貫するcでは，cの方が少し大きな振幅 值が測定されているが，これは圧力管の振動を受けや すい位直にcがあるためであるか，模擬棒の曲りが大 きいためであるか原因は不明である。いずれにせよ， 二相流の場合注乱れの大きさが支配的となるためか， $\mathbf{a}$ も $\mathbf{c}$ るとんど同じ振幅值が得られた。

テスト部架台あるいは配管の振動が，流れによる模 擬棒の振動振幅にどの程度影響していたがついて検 討しておく。二相流の場合の実験結果では，湘定され た振幅值が水流量炕無関保でボイド率に上って注济定 まっているが，このことは測定された振幅が架台ある いは配管の振動の影響よりも，然料体内の二相流動特 性によって支配されたるのであることを示していると 判断される。すなわち，るし架台あるい酒管の振動 が大きく影響しているとするならばこれらの振動量 は当然，水流量に最も大きく作用されると考号られる。 事実は，模擬棒の振動振幅が水流量に注とんど無関係 で，辛就率のみによって定まっている訳である から，架台あるいは配管の振動の影響よりも，ボイド 率の增大に伴う流路内の乱れが模擬棒の振動に支配的 であったと判断される。

\section{（3）流れによる棒の定常的な曲り}

変位量としては小さかったが，流水中で振動する模 擬棒は定常的な変位量を有し，その変位值を中心とし て振動していることが計測された。模擬棒中央におけ る歪量からその点において子測される最大の変位量を 与える条件として，スペーサー支点に曲げモーメント のみが加えられたと仮定した場合の棒中央に括ける变 位量を計算した。

この結果によると，ATR 燃料集合体における単相 流の場合，Fig. 5 (b)に示されるよらにa,b,cの各模擬 棒ともオーダとして同程度の曲りによる定常的な変位 が考兄られる。しかし，二相流では振動による振幅が 大幅に增加するのに対し，定常的な曲りははとんど增 加せず，振動振幅値に比べて 1 析以上小さい。定常的 な曲り量は振動振幅值に比へて無視しうるほよ゙小さい とみなせるので，Fig.6(b)にはこれを省略した。

\section{マ. 従来の実験式との比較}

Burgreen(1), Paidoussis(5)およびReavis(夰がそれでれ提 出した実験式を用いて，本報に和ける実駼条件での水 単相流ならびに空気ー水二相流に括ける模擬棒の振動 振幅を計算し，その結果を実験值とともに Fig. 5 (a), (b) 〜 6(a), (b)に示した。これらの四に示されるように, 前 
述の実験式によって計算される振動振幅は本報におけ る実験結果と比べて，ATR 用模擬棒 b の単相流の場 合を除いて1桁以上も小さい值となった。この原因は これらの実験式を壿くに当って採用したデータの実験 条件が本報に打けるものと大きく異なる点があるこ と，また各実験式中で考感されている影䅧因子が不充 分あるいは不適当であることによると考えられる。

以下に，各実験式についてその原因を述べる。

まず，3つの実験式に共通の記号を示す。
$d:$ 棒の直径,
$d_{h}:$ 流路の水力直径

$E I:$ 棒の剛性,

$L:$ 棒の長さ

$u:$ 流路内の水の平均流速

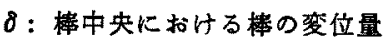

$\rho_{w}:$ 流体の密度, $\omega ：$ 棒の自然角周波数

$\rho_{r}:$ 棒の密度, $A ：$ 棒の断面穔

$\nu$ : 流体の動粘性保数

1. Burgreen の式の場合

これは単相流中にお朽る棒の掁幅に対する串験式て あり，次のよらに表わされる。

$$
\left(\frac{8}{d}\right)^{1.8}=0.83 \times 10^{-10} K_{1} \Gamma^{1 / 8} \Omega
$$

ここで, $K_{1}$ : Load deflection end-fixity factor $=(10+\alpha L) /(2+\alpha L)$

$\Gamma:$ 棒の横振動に関する無次元パラメータ $=\rho_{u} u^{2} L^{4} / E I$

$\Omega:$ 棒の横振動佀関する無次元パラメータ $=p_{v} u^{2} / \mu \omega$

$\mu:$ 水の粘性係数

$\alpha L$ : End-fixity（棒支持部の変形に対 $し て$ $y^{\prime \prime}=\alpha y^{\prime} て ゙$ 定義される棒の端末に扣け 当固定度）

Burgreenがこの実験式を導く祭に採用したデータの実 験条件注本報におけるるのと次の 2 点において異なっ ている。

(1) 振動計測用棒が $\mathrm{Al}$ の丸棒あるいは中空棒であ るため，棒の単位長さ当りの重量が実際の燃料棒 に比べて非常に小さい。

（2）模擬棒のスペーサーによる支持間隔が1,200 mm であり，本報の場合の392ならびに804 mmに比べ てずっと大きい。

以上の 2 項目が流水中の棒の振動現象にどのよ5に 関係するか火ついて考察する。

項目(1)について：梅が水中を振動する時水水から 受ける加速抵抗力は，樯を横切る流れをボテンシャル 流れとして考克ると $\rho_{w} A$ に比例している。一方， $\rho_{\mathrm{r}} A$
は棒の慣性力に比例するから，水中を振動する棒が堿 衰する割合は $\rho_{w} / \rho_{r}$ が関保する。ところが，Burgreen の式では水の粘性による抵抗恃考慮されていても加速 抵抗は考虑されていない。

したがって，非常に軽量の模擬棒を用いたBurgreen の実験では，重い棒の場合に比べて水の加速抵抗によ る減哀力が大きく作用しており，このよらなデータを 基にして作られた実験式では重い棒に対して実際より す小さな振幅値を計算することになる。

さらに，棒が水から与克られる加速度については次 項で考察する。

項目(2)について：振動する棒が流水中で受ける外 力，すなわら振動を励起し持続させる力として流水中 の乱れを考えるとき，棒の支持間隔 $L か ゙$ 棒全体に加え られる励振力関係する。すなわち，流水中の乱れは 空間的にある大きさの範囲を持って，空間的炕も強度 的にもランダムに变化していると考克られるので，支

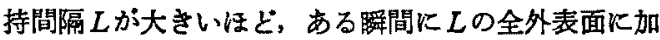
えられている外力の合成值は小さくなると考えられ る。事実，本報における実験結果でも実験值はBurgreen の式に上る計算値よりる全体に大きったが， $L=392$ $\mathrm{mm}$ の場合よりも $804 \mathrm{~mm}$ の場合の方が振幅值は小さ く計算值により近かった。

Burgreenの式炕おいて考虑されている外力は，流体 の流れ方向の運動エネルギーに比例する力を考文てい るのみであって，上述のような乱れの特性てついての 配虑はなされていない。

\section{Paidoussis の式の場合}

単相流中ならびに気液二相流中に就ける棒の振幅に 対する実験式であり，次の上うに表わされる。

$$
\begin{gathered}
\frac{\delta}{d}=\alpha_{1}^{-4}\left[\frac{U^{1.8} \varepsilon^{1.8} N_{R}^{0.25}}{1+U^{2}}\right]\left[\left(\frac{d_{h}}{d}\right)^{0.4}\right] \\
\cdot\left[\frac{\beta^{2 / 3}}{1+4 \beta}\right]\left[5 \times 10^{-4} K\right]
\end{gathered}
$$

$こ こ て ゙$,

$\alpha_{1}$ : 棒の 1 次モードの振野における 固有值 $\alpha_{1}^{2}=\left\{(m+M) L^{4} / E I\right\}^{1 / 2} \omega_{1}$

$\omega_{1}$ : 静止流体中の棒の自然角周波数

$m:$ 棒の単位長さ当りの質量

$M$ : 棒の振動時, 単位長さ当りに付加される 流体の留量 $=1 / 4 \pi d^{2} \rho_{v}$

$U:$ 無次元流速 $=(M / E I)^{1 / 2} u L$

$\varepsilon: L / d$

$\beta: M /(M+m)$

$N_{R}:$ レイノルズ数 $u d_{R} / \nu$ 
$K ：$ 竫がな整流状斯では 1，乱流中では 5 とする。

Paidoussis がこの実験式を導く際に採用したデータ の実験条件が本報に利けるむのと次の 2 点に拈いて異 なっている。

(1) 円管流路に算一模擬棒が直かれた場合の実験デ 一タが主である。 Burgreen のデータる使ってい る。

(2) 二相流によるデータは Quinnのものを使って いるが,このデータは小口径(最大 $41.4 \mathrm{~mm}$ )の円 管流路での単一模擬棒による実験結果である。 以上の 2 項目について前項と同粎に考察する。

項目(1)について： 実際の然料集合体では多数の然 料棒が大さな的管径の中に配直されており，したが って,水力直径は小さいけれどむ流路断面䅡は大きい。 そのため，流路内の乱れは小口经の円管流路に比べて かなり大きいと考えられる。このことは項目(2)で述べ るよらに二相流の場合顕著である。水単相流の場合に は，管束流路では水を介して隣接する然料棒の振動を 受けやすいことが考えられる。

項目(2)について：常温・常王の空気一水二相流の観 察結果によると，実際の然料集合体に和いては二相流 動状熊は内徍50 mm 以下の円管流路に沶ける流動状熊 と大いに異なり，ボイド率が $60 \%$ 程度となってす気泡 流であるといら事実(8)を認識する必要がある。この事 春は，然料体の上らな水力直径は小さくとも流路断面 積が大きい流路では，流れに乱れが大きいためボイド 率が增大しても気泡流の状態からスラグ流や環状流に 要移しにくいことを示崚している。すなわち，気泡が 合体してスラグ状の大きな気泡が流路内の一部に発生 すると, 大気泡の周囲との間に生ずる比重差ならびに 流路断面櫝が大きいため周囲に乱れを生じやすくなっ ていることなどのために，直るにその大気泡を猿すよ らな力が発生するであるう。つまり，このよらな二相 流では気泡群それ自身が流れの乱れを登生させる要因 となっていると考えられる。

本報における二相流中で模挠棒の振動振幅デーダが 水流量に無関保でポイド率のみによって定まることを 示しているのは，以上の流れ機構を裹付ける一つの事 実と考えられる。

3. Reavis の式の堛合

単相流中に和ける棒の振幅に対する半理論式であ り，次のように表わされる。

$$
W V I=c \eta_{\varangle} \eta_{\Theta_{n}} \eta_{\varepsilon} \frac{d L N^{0.5}}{W f_{n}^{1.55} \zeta^{0.5}} u \rho_{w} \nu^{0.5}
$$

$こ こ て$

WVI：棒中央における最大変位量

$c$ : 補正保数(文献(6)の Fig. 3 に示される)

$\eta_{a}$ : 棒直径に上って定まる俰数(文献(6)の

Fig. 1)

$\eta_{d_{A}}$ : 流路の水力直径によって定末る係数（同上）

$\eta_{L}$ : 棒の長さに上って定まる俰数(同上)

$f_{n}:$ 棒の自然振動数 $(\mathrm{Hz}) f_{n}=\omega_{n} / 2 \pi$

$N:$ 棒の本数

$W: N$ 本の棒の重量

$\zeta:$ 隇衰保数 $\left(\omega_{d}=\sqrt{1-\zeta^{2} \omega_{n}}\right)$

$\omega_{a}:$ 流水中の棒の角周波数

[筆者註](1) Nの指数0.5は 1 の唄りと思われる。 実際の計算では $W を N=1$ の時の重量にとれば同 じ。(2)Wの䍩位は重量となっているが，質量でな いとWVIのと元が長さにならない。望量の譟り と思われるか，原論文では重量とした場合のcが 求められてあり，この場合のcは留量とした場合 の正しいcの g(重力加速度)倍の值となっている ことに注意する必要がある。なお，原論文では $\mathrm{g}$ $=386 \mathrm{in} . / \mathrm{sec}^{2}$ が用いられている。

Reavisの式は，不規則外力が構造物に加えられる時 の振幅の RMS 応答に関する振動理論を基にして導か れた，乱流中に蹎かれた棒の RMS応答振幅の式であ る。この方法によると，棒の支持間隔に加えられる不 規則外力に関する正確な情報が与えられるならば，振 動の運動方程式の解として RMS 振幅值が理諭的に求 まるので，かなり正碓な表示式となるはずである。

しかしながら，実慗の然料集合体のような管束流路 内の圧力変動の分布を澌定したデータが見当らないの で, Reavisは Corcos ${ }^{(1)}$, Baroudiら (12)ならびK Bakewell ${ }^{(13)}$ によって求められた，空気が流れる円管の内表 面の圧力変動に関するデータを使っている。そして， 振幅値については Burgreen, Quinn, Sogréah 扰よび Pavlicaらによって求められた単一ならびに複数本振動 棒を有する流路での実験結果と比較し，理論式に(水力 直径)/(棒の長さ)の関数によって与えられる補正係数 cを恭ずることによって実験値と一致するよらになる としている。

補正俰数 $c$ 注種々の大きさの水力直径を含むデータ から求められているが, Pavlicaのものを除いて，全部 円管流路に単一の振動棈が硻かれている場合の実験デ ータである。Pavlicaのるのは振動棒の重量に関しては 実妒の場合に近いが，棒の長さが大きく，また 1 辺が $60 \mathrm{~mm}$ の正方形流路内に16本の振動棒が直かれた場合 
のものであるので，実際の然料集合体と比べると流路 断面積が小さい。その結果, 本実験式からす Burgreen ならびに Paidoussisの式による計算値とほぼ同じき さの計算結果しか得られなかった。

なお，Reavisは不規則外力による構造物の RMS 応 答振幅の式から, 乱流中の棒の RMS 応答振幅值を求 める式を導く垱っって次の仮定あるいは近似を行なっ ているので，実際に適用する場合，これらの条件炕大き く反しないかどうかを前もって検討する必要がする。

(1) 流路内に扔ける代力変動特性として, 空気流 と水流の相違ならびに円管流路壁面之燃料集合 体流路内の然料棒表面の相違を無視している。

(2) 然料体内にあるスペーサーが流れの乱れに及 ぼす影響ならびに燃料棒の振動が圧力変動に及 ぼす影響を無視している。

(3) 燃料棒の振動モードは両端支持状態の 1 次モ ードとしている。

(4) 棒の固有振動数付近で棒表面の任意の 2 点間 に和ける压力変動のクロス・パワースペクトル 分布を一様としている。

（5）然料棒の平均密度に比べて流体の密度を 2 次 の繁小項として無視している。

\section{1. 結 論}

JPDR-II 用燃料集合体ならびに ATR 用然料集合体 に括ける冾却材流れによる然料棒の振動を常温・常仕 の水単相流ならびに空気一水二相流中で実験した結果 から，水力直径は小さいか流路断面積は大きい，上記 の上うな実規模燃料集合体内では，次の上らな振動特 性を示すことが明らかにされた。

(1) 実規模燃料集合体内に和ける然料棒の振動振幅 は，二相流の場合単相流に比べて約 1 析大きくな る。

(2) 二相流における然料捀の振動振幅は, 水流量に はほとんど無関保でボィド率のみによって定ま る。

（3）二相流における然料棒の振動数は，その周波数 分析結果によると、ボイド率の低い時は然料棒の 固有振動数成分がはっきりと卓越していることが 認められるが，ボイド率の増大とともにその卓越 性は薄れて来てフラットな分布に近つく。この傾 向はスペーサーによる支持間隔が大きいほど顕著 である。

（4）流れに上る棒の振動は，流れの乱れに起因寸る 流路内のランダムな代力变動が棒表面に加えら
れ，そのうちの固有振動数成分に応答して棒が振 動する場合と、ランダムな強い殴力変動にそのま

ま応答して振動する場合があることが示唆された。 従来の実験式と本報の実験值との比較を行い，両者 の相逢が生ずる原因について考察した結果, 次の結論 を得た。

（5）従来の実験式が作られるに当って採用されたデ 一タの実験条件が実祭の然料集合体中に战ける燃 料棒の振動条件と大きく異なっでり，それが実 験式の中で充分考慮されていないこと。具体的に は模擬棒の単位長さ当りの重量, 模擬棒の支持間 隔ならびに流路の形状・寸法などの相違が流れに よる棒の振動に関係しており，それらが実験式の 中に充分考虑されていないことである。

（6）水力直径住小さいが，流路断面積は大きい実際 の然料集合体流路と振動実験用に作られた小さな 流路(特に円管流路に単一振動棒か：置かれた流路） 内における流れの乱れの相違が全く考虑されてい ない。

本研究を行らに当り実験を手伝っていただいた安全 工学第 2 研究室新妻 泰氏, JPDR-I燃料体に関する種 種の情報を提供していたたいいた当時然料安全第 1 研究 室長, 現安全工学部次長森島淳好氏ならびに同室員の 方々，ATR の振動計測用模擬棒の製作にご尽力いた だいた原子燃料工業湖小林行雄氏を初めとする担当者 の多，そして本報を発表するに当りいろいるお世話 になった安全工学第 1 研究室長斯波正锄氏に潹く感謝 の意を表します。

終りに, 本研究は動力炉·核然料開発事業団の委託に より行われたものを一部分含んでいるととを付記しま 才。

\section{一老考文露—}

(1) BURgReEn, D., et al.: Trans. ASME, 80, 991 1003 (1958)

(2) QUINN, E.P.: GEAP-4059, (1962).

(3) SOGRÉAH: Special Rep. No. 3, EURAEC-288, (1962).

(4) Pavlica, R.T., Marshall, R.C.: Trans. Amer. Nucl. Soc., 8, 599 (1965).

(5) Pardoussis, M.P.: Nucl. Sci. Eng., 35, 127 138 (1969).

(6) REAvis, J.R.: ibid., 38, 63 69 (1969).

(7) 盛崎元昭: JAERI-M 4758, (1972).

（8）岡崎元昭，他： 本会略46年会要旨集，A6，(1971)，

(9) 岡崎元昭, 山崎弥三郎: JAERI-M 5478，(1973)

(60) 同 上: JAERI-M 5885, (1974).

(11) Corcos, G.M.: Inst. Eng. Res., Ser. No. 193, Issue No. 2, p. $65 \sim 66$ (1962).

(12) BAROUDI, M.Y., et al.: AGARD-465, (1963).

(19) BAKEWElL, H.P., Jr.: J. Acoust. Soc. Amer., 36 [1], $146(1964)$ 